\title{
PONTICOLA IRANICUS SP. NOV. (ACTINOPTERYGII: PERCIFORMES: GOBIIDAE) FROM THE CASPIAN SEA BASIN
}

\author{
Ekaterina D. VASIL'EVA ${ }^{1 *}$, Hamed MOUSAVI-SABET ${ }^{2}$, and Victor P. VASIL'EV ${ }^{3}$ \\ ${ }^{1}$ Zoological Museum, Moscow State University, Moscow, Russia \\ ${ }^{2}$ Department of Fisheries, Faculty of Natural Resources, University of Guilan, Sowmeh Sara, Guilan, Iran \\ ${ }^{3}$ Severtsov Institute of Ecology and Evolution, Russian Academy of Sciences, Moscow, Russia
}

\begin{abstract}
Vasil'eva E.D., Mousavi-Sabet H., Vasil'ev V.P. 2015. Ponticola iranicus sp. nov. (Actinopterygii: Perciformes: Gobiidae) from the Caspian Sea basin. Acta Ichthyol. Piscat. 45 (2): 189-197.
\end{abstract}

\begin{abstract}
Background. Five species of Ponticola have hitherto been recognized among freshwater gobies in the PontoCaspian basin. In 2014 a number of specimens representing this genus were collected in northern Iran. The detailed morphological and karyological study of those gobies collected revealed significant differences between them and their known congeners. The aim of this study was to describe these fish as a new species from the Caspian Sea basin. Materials and methods. The fish specimens were collected in August 2014 at two localities of the Sefid-Rud River drainage, and in the Gisum River, Guilan Province, northern Iran. In total, 18 specimens were used for karyological study following a previously described method. Both karyotyped and intact specimens were then morphologically investigated using characters developed for study on gobiids, and particular for freshwater Caucasian gobies. The comparative materials were specimens from museum collections, as well as published descriptions, illustrations, and measurements of other species.
\end{abstract}

Results. Ponticola iranicus sp. nov. differs from its congeners in a set of the following features: $D_{1}$ VI, $D_{2} \mathrm{I} /\left(14 \frac{1}{2}\right)$ $15 \frac{1}{2}-17 \frac{1}{2}$, A I/ $10^{1 / 2}-13 \frac{1}{2}$; nape scaled completely, scales cycloid; cycloid scales covering upper part of opercle; lateral line system with posterior sub-orbital row $d_{2}$ continuous; predorsal area uniform, dark grey; first dorsal fin with oblique black stripe between first two or three rays; short dark grey strip on upper part of pectoral fin base; karyotype consisting of 46 acrocentric chromosomes.

Conclusion. All known Ponto-Caspian gobies demonstrate mosaic pattern of morphological and karyological features that presumes their polyphyletic origins. Further phylogenetic studies by molecular genetic methods are necessary for identification of their marine ancestors and clarifying of common trends in the evolution of the Ponto-Caspian goby group.

Keywords: Ponticola iranicus sp. nov., description of a new species, freshwater gobies, taxonomy, PontoCaspian basin, Iran

\section{INTRODUCTION}

The Caspian Sea basin belongs to the Ponto-Caspian biogeographical region, encompassing the basins of the Black, Azov, Caspian, and Aral Seas (Berg 1949). The native fish fauna of the Caspian Sea basin consists of an estimated 162 fish species, 100 of them being endemic species or subspecies (Bogutskaâ et al. 2013); many of them of commercial importance.

The fishes of the family Gobiidae inhabiting the area are usually less important commercially and therefore knowledge on their biodiversity is far from being complete (Miller 2003, 2004, Bogutskaâ et al. 2013).

A total of eight gobiid species have been recorded in the Caspian Sea basin (Miller 2003, 2004). They repre- sent three genera: Neogobius Iljin 1927, Chasar Vasil'eva, 1996, and Ponticola Iljin, 1927. The former genus includes three species: Neogobius caspius (Eichwald, 1831), Neogobius melanostomus affinis (Eichwald, 1831), and Neogobius fluviatilis pallasi (Berg, 1916) (see Miller 2003). One species belongs to a monotypic genus Chasar and it is a deep-water goby: Chasar bathybius (Kessler, 1877) (see Miller 2004). The third genus Ponticola, accepted after molecular-genetic studies (Neilson and Stepien 2009, Medvedev et al. 2013), accommodates remaining four species: Ponticola gorlap (Iljin, 1949), Ponticola syrman (Nordmann, 1840), Ponticola ratan (Nordmann, 1840), and Ponticola cyrius (Kessler, 1874).

\footnotetext{
" Correspondence: Dr. Ekaterina D. Vasil'eva (Екатерина Васильева), Зоологический музей, Московский государственный университет, Большая Никитская 6, Moskva, 125009 Russia, phone:+7 495 6294906, fax:+7 495 6294825, e-mail:(EDV)vas_katerina@mail.ru,(HMS)mousavi-sabet@guilan.ac.ir,mosavii.h@gmail.com, (VPV)vasvik1943@gmail.com
} 
The genus Ponticola includes at least ten species characterized by several common morphological characters, namely anterior pelvic membrane with well developed, acute lateral lobes; dentary with several large conical teeth on its rear part; maxilla with expanded posterior end, and some other craniological features (Vasil'eva et al. 1993, Miller and Vasil'eva 2003).

Ahnelt and Holčík (1996) reported gobiids found in small rivers of the Anzali Lagoon, Guilan Province, northern Iran as Ponticola cyrius. The latter finding is important from the perspective of the presently reported study.

In August 2014, we succeeded in collecting numerous samples of gobies in the Sefid-Rud River and Gisum River in Guilan Province, northern Iran. The detailed morphological study showed that these gobies are conspecific with the populations from the Anzali Lagoon previously identified as $P$. cyrius. However, morphological data, as well as karyological analysis revealed noticeable differences between all of these fishes and other known Ponticola species including $P$. cyrius. The goal of this study is the description of a new goby species from the Caspian Sea basin based on our new materials but also considering the data from Ahnelt and Holč́́k (1996).

\section{MATERIALS AND METHODS}

The specimens were collected on August 8, 2014 in two localities of the Sefid-Rud River drainage: the Sahrebijar Stream in its lower part $\left(37^{\circ} 01.153^{\prime} \mathrm{N}, 049^{\circ} 37.985^{\prime} \mathrm{E}\right)$, and the Tutkabon Stream in the upper part $\left(36^{\circ} 50.756^{\prime} \mathrm{N}\right.$; $\left.049^{\circ} 35.021^{\prime} \mathrm{E}\right)$, as well as in the Gisum River $\left(37^{\circ} 40.512^{\prime} \mathrm{N}\right.$; $049^{\circ} 03.024^{\prime} \mathrm{E}$ ), in the southern Caspian Sea basin, Guilan Province, northern Iran (Fig. 1). Fishes were collected by scoop nets, and kept alive in aerated water from their rivers in cans of water and aquaria before karyological study.

For karyological study we used 18 specimens with total body length (TL) 56-102 mm. All specimens were injected with $0.2-0.7 \mathrm{~mL}$ colchicine solution $(0.3 \%-0.4 \%)$ depending on their weight. After $4 \mathrm{~h}$ cells of anterior part of kidney and thymus were used for chromosome slide preparing by using previously published karyological method (Vasil'ev 1978). The study was conducted by using anesthesia of fishes with a solution of MS-222. Metaphase chromosomes stained in 4\% Giemsa solution in phosphate buffer ( $\mathrm{pH}$ 6.8) were counted with PC software Quick Photo Micro. A total of 10 metaphase plates from five specimens (males and females) were suitable for further analysis. The chromosomes were classified according to the systems suggested by Levan et al. (1964).

Karyotyped specimens, as well as several intact ones after removal of fin clips for further molecular-genetic investigations were fixed in $4 \%$ formaldehyde solution. For morphological analysis we used characters developed for study on gobiids (Miller 2003), and particular for Caucasian freshwater gobies (Vasil'eva and Vasil'ev 1994b). All measurements were made point to point and recorded with precision of $0.1 \mathrm{~mm}$. The last two branched rays articulating on a single pterygiophore in the second dorsal $\left(D_{2}\right)$ and anal $(A)$ fins are noted as " $1 \frac{1}{2} 2$ ". For lateral line system we used terminology from Miller (1986). The number of studied specimens is presented in the description of the new species. For comparative morphological analysis we calculated mean values and standard deviations] for the sample included the holotype and paratypes on all morphometric characters. As a comparative material we used the following samples from the collection of the Zoological Museum of the Moscow State University (ZMMU).

- Ponticola cyrius: ZMMU P-4274, Kura R. at Borzhom, 4 spec.; P-17491, Khrami R., 17 spec.; P-19235, Kura R. at Borzhom, 37 spec.; P-19236, Kura R. at Akhaldabo, 30 spec.; P-19237, Tbilisi reservoir, 15 spec.

- Ponticola gorlap: ZMMU P-16835, Kura R. basin at Mingechaur, 26 spec.; P-23315, Bol'shoi Uzen' River, 28 spec.; P-23660, Sefid-Rud R., 9 spec.

- In this study we also used data, previously obtained by our investigations of the type specimens in the collec-

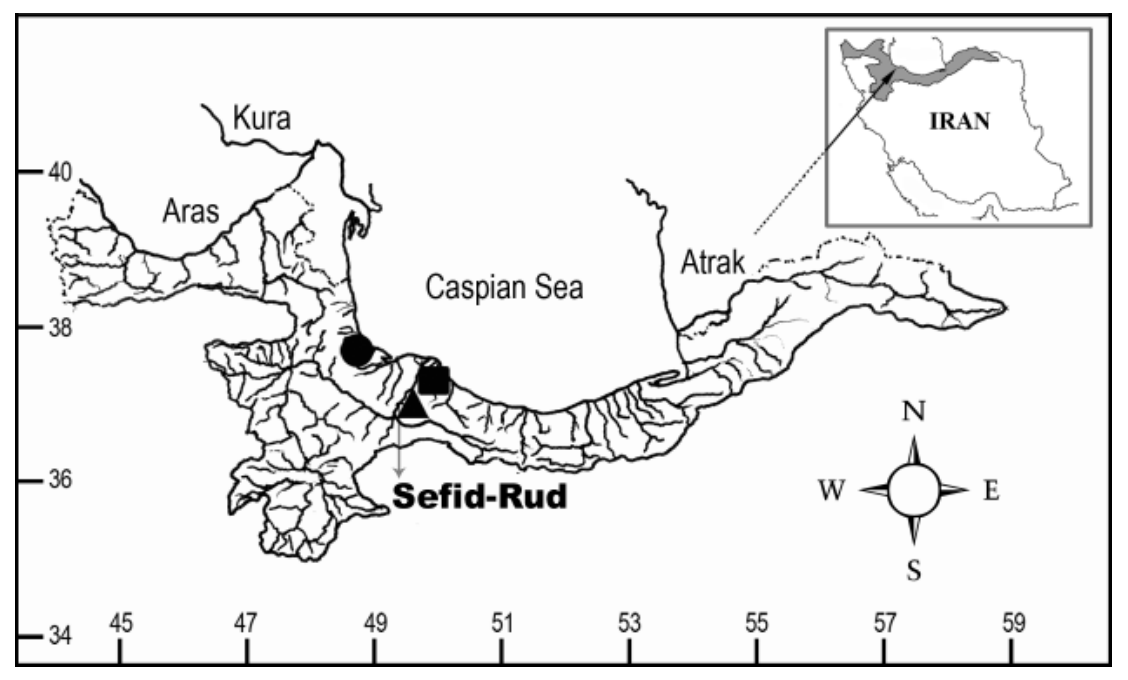

Fig. 1. Iranian southern Caspian Sea basin showing some of the most important river system and the sampling sites; Tutkabon and Shahrebijar streams in the Sefid-Rud River drainage; Gisum River 
tion of Zoological Institute of Russian Academy of Sciences (S.-Petersburg) (ZIN):

- Gobius cyrius (ZIN 2235, 3 spec.) and

- G. weidemanni Kessler, 1874 (ZIN 2224, 2 spec.); as well as

- the syntype of G. constructor Nordmann, 1840 in the collection of Muséum National d'Histoire Naturelle (Paris) (MNHN) (MNHN A-1196) (Vasil'eva and Vasil'ev 1994b).

Other data on morphological features of different Ponto-Caspian gobies used in this work were earlier presented in our many publications and in Miller 2003, 2004.

Type specimens, as well as fishes used as additional material are kept in the ZMMU, in Guilan University ichthyologic collection (GUIC), and in the Vatandoust and Mousavi-Sabet fish collection, Tehran (VMFC).

\section{RESULTS AND DISCUSSION}

Ponticola iranicus sp. nov. (Figs. 2-4)

Gobius platyrostris cyrius (non Kessler, 1874): Deržavin 1926: 181 (part.: Sefid-Rud - partim). Deržavin 1934: 116 (part.: tributaries of the Sefid-Rud - partim).

Gobius (Ponticola) platyrostris cyrius (non Kessler, 1874): Il'in 1927: 141 (part.: northern Persia).

Neogobius cephalarges constructor (non Nordmann, 1840): Berg 1949: 1087 (part.: rivers of the south Caspian coast).

Neogobius cyrius (non Kessler, 1874): Ahnelt and Holčík 1996: 103.

Ponticola cyrius (non Kessler, 1874): Esmaeili et al. 2010: 378 (partim). Coad 2015: part.: Anzali Mordab and tributaries.

Type material. Holotype. ZMMU P-23677, female, TL $81 \mathrm{~mm}$, standard body length (SL) $68 \mathrm{~mm}$, upper Sefid-Rud River basin, Tutkabon Stream, $36^{\circ} 50.756^{\prime} \mathrm{N}$, 049³5.021'E, 08 August 2014.

Paratypes. ZMMU P-23678, 7 females, 2 males (6 karyotyped) TL 80.5-99.0 mm, SL 65.0-83.0 mm, Sefid-Rud River basin, $36^{\circ} 50.756^{\prime} \mathrm{N}, 049^{\circ} 35.021^{\prime} \mathrm{E}$ and $37^{\circ} 01.153^{\prime} \mathrm{N}, 049^{\circ} 37.985^{\prime} \mathrm{E}, 08$ August 2014.

Additional material. ZMMU P-23679, 5 spec. (4 karyotyped) TL 59.0-73.5 mm, collected together with paratypes; ZMMU P-23680, 10 spec. (5 karyotyped) TL 40.2-77.0 mm, Gisum River, $37^{\circ} 40.512^{\prime} \mathrm{N}, 049^{\circ} 03.024^{\prime} \mathrm{E}, 08$ August 2014; GUIC POI-AM, 7 spec. TL 44.1-79.5 mm, Gisum River, $37^{\circ} 40.512^{\prime} \mathrm{N}, 049^{\circ} 03.024^{\prime} \mathrm{E}, 11$ December 2014; VMFC POI-P, 9 females, 3 males TL 75.2-98.5 mm, SL 61.1-82.4 $\mathrm{mm}$, Sefid-Rud River basin, $36^{\circ} 50.756^{\prime} \mathrm{N}, 049^{\circ} 35.021^{\prime} \mathrm{E}$ and $37^{\circ} 01.153^{\prime} \mathrm{N}, 049^{\circ} 37.985^{\prime} \mathrm{E}, 27$ October 2013.

Diagnosis. A species of the genus Ponticola; $D_{1} \mathrm{VI}, D_{2} \mathrm{I} /$ (141/2) 151/2-171/2, A I/101/2-131/2; nape scaled completely, scales cycloid; cycloid scales covering upper part of opercle; lateral line system with sub-orbital row $d$ continuous; predorsal area uniform, dark grey; first dorsal fin with oblique black stripe between first two or three rays; short dark grey strip on upper part of pectoral fin base; karyotype consisting of 46 acrocentric chromosomes.

Description of holotype. $D_{1} \mathrm{VI}, D_{2} \mathrm{I} / 15^{1 / 2}, A \mathrm{I} / 12 \frac{1}{2} ; 1.1$. 62 . Body laterally compressed, gradually decreasing from head to tail; caudal peduncle elongated, high; minimum body depth containing slightly less than 1.5 times in caudal peduncle length; first and second dorsal fins almost touching with their bases; second dorsal fin of uniform height; head relatively high and short, its length containing 3.4 times in SL; head width slightly larger than depth; slightly swollen cheeks; nape scaled completely, scales cycloid; cycloid scales cover upper part of opercle; lower jaw slightly protruding; upper lip expanding in middle and slightly swollen, with sharpened end; pelvic disc elongated, its length about 0.7 ventro-anal distance, not reaching anus; anterior pelvic membrane with well developed pointed, but short lateral lobes, their length containing about 6 times in membrane length; pectoral fins reach base of first dorsal branched ray, noticeably not reaching anus; caudal fin rounded; coloration of preserved holotype yellowish grey (after transfer from formaldehyde to $75 \%$ alcohol); sides of body with marble pattern: irregular pale yellow spots on grey background; predorsal area uniform, dark grey; belly light, yellowish, with numerous small dark grey speckles; clear line of dark grey long longitudinal stripes along midline of sides; fins grey, ventral and anal fins yellowish-grey; light edging present along outer margin of second dorsal, ventral, anal, and caudal fins; second dorsal fin with indistinct transverse rows of darker grey spots; three transverse rows of spots on first dorsal fin; clear oblique black stripe between first and second rays of first dorsal fin; short dark grey strip on upper part of pectoral fin base. Morphometric characters presented in Table 1.

Extended description based on all type specimens. Overall meristic characteristics: $D_{1}$ VI, $D_{2} \mathrm{I} /\left(14^{1 / 2}\right) 15^{1 / 2}$ $17 \frac{1}{2}$, A I/101/2-131/2; 1.1. 54-70; The specimens from the Sefid-Rud River usually have $15 \frac{1}{2}$ or $16 \frac{1}{2}$ branched dorsal rays (46.7\% each) and $11 \frac{1}{2}$ branched anal rays (60.0\%); in the Anzali Lagoon specimens with $16 \frac{1}{2}$ dorsal rays and $12 \frac{1}{2}$ anal rays were predominant $(73.7 \%$ and 68.4\%, respectively) (Ahnelt and Holč́k 1996 counted the last two branched rays articulating on a single pterygiophore as one ray), and in the Gisum River the majority of specimens have $15 \frac{1}{2}$ dorsal rays $(80.0 \%)$ and $11 \frac{1}{2}$ anal rays $(50.0 \%)$. The majority of specimens from the Sefid-Rud and Gisum rivers have 55-60 scales in lateral series, in the Anzali Lagoon: 57-58 scales. Studied specimens have a relatively short body, laterally compressed at caudal peduncle; caudal peduncle elongated and high, minimum body depth contains $1.5-1.9$ times in caudal peduncle length; head relatively high and short, its length contains 3.0-3.4 times in SL; head width slightly larger than depth, cheeks swollen; interorbit distance not wide: in specimens from the Sefid-Rud River it varies from 0.4 to 0.8 eye diameter, in fishes from the Gisum River-from 0.4 to 0.5 , and from the Anzali Lagoon-from 0.3 to 0.7 (in average 0.5 ); lower jaw sometimes slightly protruded, usually upper and low jaws are of the same length; upper lip expanded in the middle and slightly swollen; pelvic disc sometimes reaching anus or even extending beyond anus in smaller specimens; other features are as in the holotype. Morphometric characters of 

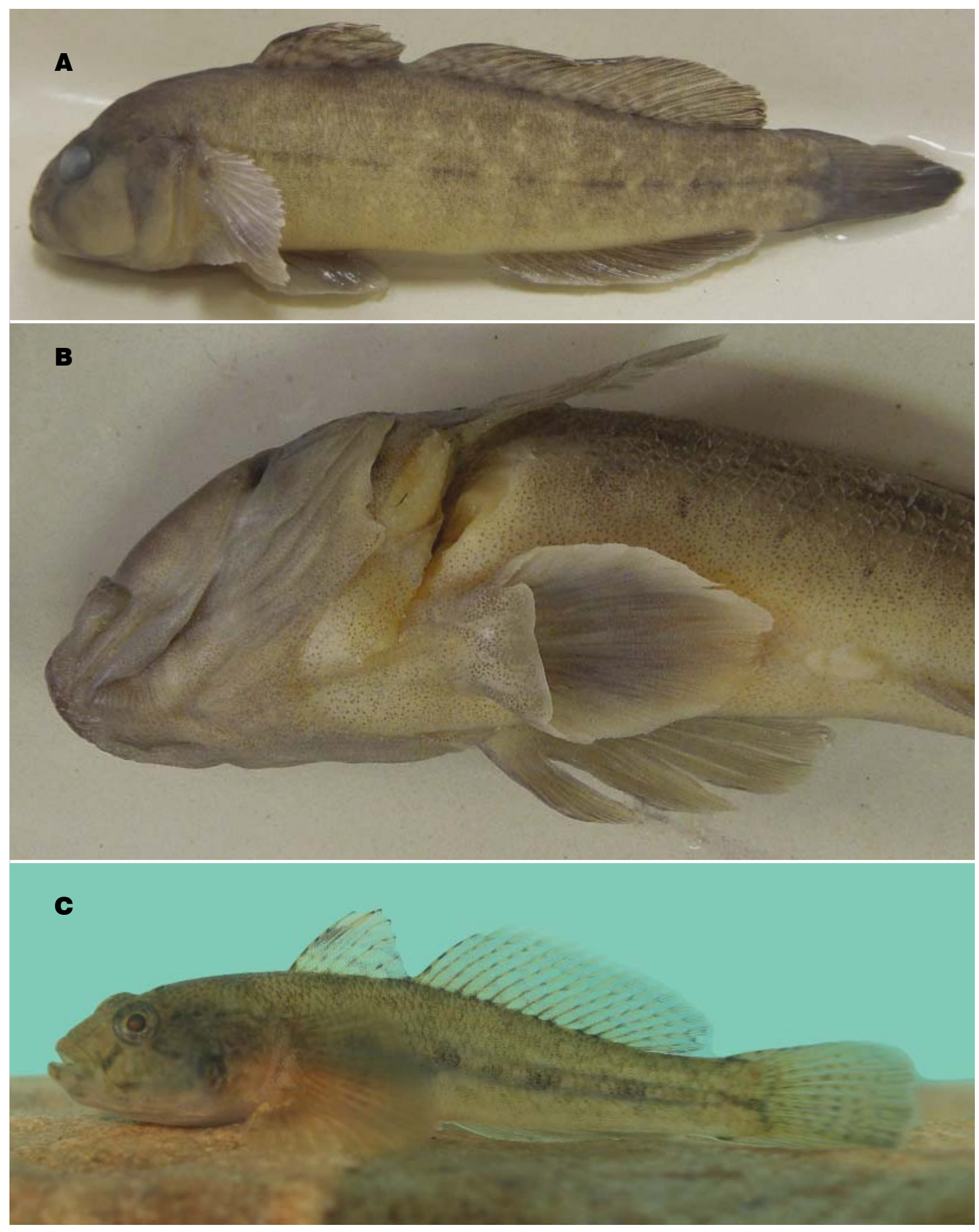

Fig. 2. Ponticola iranicus sp. nov.; holotype, ZMMU P-23677, female, TL $81 \mathrm{~mm}$ (A); pelvic disc in the paratype, ZMMU P-23677, female, TL 99 mm (B); living specimen from the Gisum River (C) 
Table 1

Morphometric characters (ranges, means, and standard deviation) of type specimens of Ponticola iranicus sp. nov.

\begin{tabular}{|c|c|c|c|c|}
\hline & \multirow{2}{*}{ Character } & \multirow{2}{*}{ Holotype } & \multicolumn{2}{|c|}{ Paratypes + holotype $(n=10)$} \\
\hline & & & Range & Mean \pm SD \\
\hline & $\mathrm{TL}[\mathrm{mm}]$ & 81.0 & $80.5-99.0$ & $89.3 \pm 7.72$ \\
\hline & $\mathrm{SL}[\mathrm{mm}]$ & 68.0 & $65.0-83.0$ & $73.2 \pm 6.60$ \\
\hline & A & 12.5 & $11.5-12.5$ & $12.2 \pm 0.68$ \\
\hline & $\mathrm{D}_{2}$ & 15.5 & $15.5-16.5$ & $16.1 \pm 0.52$ \\
\hline \multirow[t]{13}{*}{$\% \mathrm{SL}$} & $H$ & 21.6 & $20.6-23.5$ & $21.9 \pm 0.85$ \\
\hline & $h$ & 11.8 & $11.4-12.3$ & $11.8 \pm 0.59$ \\
\hline & $\mathrm{pD}$ & 33.8 & $33.0-36.9$ & $34.5 \pm 1.20$ \\
\hline & $1 \mathrm{D}_{2}$ & 36.0 & $35.1-39.6$ & $37.1 \pm 1.52$ \\
\hline & $\mathrm{HD}_{2}$ & 13.5 & $13.3-16.3$ & $15.1 \pm 1.01$ \\
\hline & $\mathrm{pA}^{2}$ & 55.2 & $54.4-58.7$ & $56.5 \pm 1.61$ \\
\hline & $1 \mathrm{~A}$ & 23.1 & $21.7-26.5$ & $24.1 \pm 1.65$ \\
\hline & IP & 25.3 & $25.3-28.9$ & $27.3 \pm 1.35$ \\
\hline & $1 \mathrm{~V}$ & 21.0 & $18.5-22.1$ & $20.6 \pm 1.07$ \\
\hline & lpc & 17.9 & $17.9-22.1$ & $19.5 \pm 1.38$ \\
\hline & lapc & 7.2 & $6.5-8.2$ & $7.5 \pm 0.59$ \\
\hline & lapc1 & 3.1 & $2.5-4.0$ & $3.3 \pm 0.53$ \\
\hline & lc & 29.7 & $29.2-32.5$ & $30.8 \pm 1.18$ \\
\hline \multirow[t]{7}{*}{$\%$ lc } & $\mathrm{Oh}$ & 19.8 & $16.6-21.5$ & $19.6 \pm 1.45$ \\
\hline & prO & 33.7 & $28.2-38.3$ & $32.5 \pm 2.72$ \\
\hline & poO & 50.5 & $49.4-54.2$ & $52.0 \pm 1.79$ \\
\hline & io & 12.4 & $9.2-14.9$ & $11.3 \pm 1.66$ \\
\hline & laLB & 10.9 & $8.3-10.9$ & $10.0 \pm 0.76$ \\
\hline & hc & 66.8 & $64.3-75.7$ & $69.4 \pm 3.34$ \\
\hline & lac & 76.7 & $71.0-79.6$ & $75.9 \pm 2.55$ \\
\hline
\end{tabular}

$\mathrm{SD}=$ standard deviation, $\mathrm{TL}=$ total body length, $\mathrm{SL}=$ standard body length, $A=$ number of anal fin branched rays, $D_{2}=$ number of the second dorsal fin branched rays, $H=$ maximum body depth, $h=$ least depth of caudal peduncle, $\mathrm{pD}=$ predorsal distance, $1 \mathrm{D}_{2}=$ length of the second dorsal fin base, $\mathrm{HD}_{2}=$ height of the second dorsal fin, $\mathrm{pA}=$ preanal distance, $1 \mathrm{~A}=$ length of anal fin base, $1 \mathrm{P}=$ length of pectoral fin, $\mathrm{lV}=$ length of ventral disc, $1 \mathrm{pc}=$ caudal peduncle length, lapc $=$ width of caudal peduncle at the anal fin, lapc $1=$ minimum width of caudal peduncle, $\mathrm{lc}=$ head length, $\mathrm{Oh}=$ horizontal diameter of eye, $\mathrm{prO}=$ preorbital distance, $\mathrm{poO}=$ postorbital distance, io $=$ interorbital distance, laLB $=$ width of upper lip, hc $=$ head depth at nape, lac $=$ head width.

type specimens and a few diagnostic characteristics are presented in Tables 1 and 2. In our samples the largest specimen was a male of SL $86 \mathrm{~mm}$ and TL $102 \mathrm{~mm}$; in the Anzali Lagoon the largest male had SL $101.3 \mathrm{~mm}$ and TL 128.9 mm (calculated from Ahnelt and Holčík 1996). Coloration. Studied specimens after fixation are usually yellowish grey. Among fishes from the Gisum River two dark grey males were found, probably by reason of dark water in this river. All fins of these males were dark grey with pelvic disc somewhat lighter; lighter edging was present along the outer margin of the first dorsal and anal fins only; their belly was entirely covered by black speckles. Predorsal area in every specimen uniform, dark grey; row of elongated dark grey spots along the midline of the sides; short dark grey strip on the upper part of the pectoral fin base usually present: it was observed in $86.7 \%$ (13 spec.) of fishes studied from the Sefid-Rud River, and in all ten specimens from the Gisum River. A clear oblique black stripe on the first dorsal fin usually can be seen between the first and second rays only (78.6\% in the Sefid-Rud and $80 \%$ in the Gisum rivers); in other specimens this stripe is visible also between the second and third rays. Data from Ahnelt and Holčík (1996) are less complete, but they men- tioned a "conspicuous black spot" in anterior part of the first dorsal fin and "well visible row of 8-10 elongated dark spots along the lateral line" (p. 104).

Head lateral-line system in Ponticola iranicus is similar to the majority of the other species studied in the genera Neogobius and Ponticola (Fig. 3): neuromast organs form seven transverse rows, four (1-4) before and three $(5 s, 6 s$, and 7$)$ above hyomandibular row $b$. Row 7 consists of several papillae before anterior oculoscapular pore $\alpha$; two papillae rows below hyomandibular row $b-5 i$ and $6 i$ separated, with row $5 i$ well behind anterior end of row $b$ and row $6 i$ short of row $b$; sub-orbital longitudinal row $d$ consists of two parts: the anterior $d_{1}$ oblique, following the border of the upper lip and reaching below the anterior origin of $d_{2}$, and the posterior longitudinal row $d_{2}$; row a lacking. Anterior and posterior oculoscapular canals, and preopercular canals, present, with pores $\sigma, \lambda, \kappa \omega, \alpha, \beta, \rho, \theta, \tau$, and $\chi, \delta, \varepsilon$, respectively. Anterior oculoscapular pore $\rho$ and posterior oculoscapular pore $\theta$ well separated.

The karyotype of all investigated specimens consists of 46 acrocentric chromosomes $(2 \mathrm{n})$; the number of chromosome 


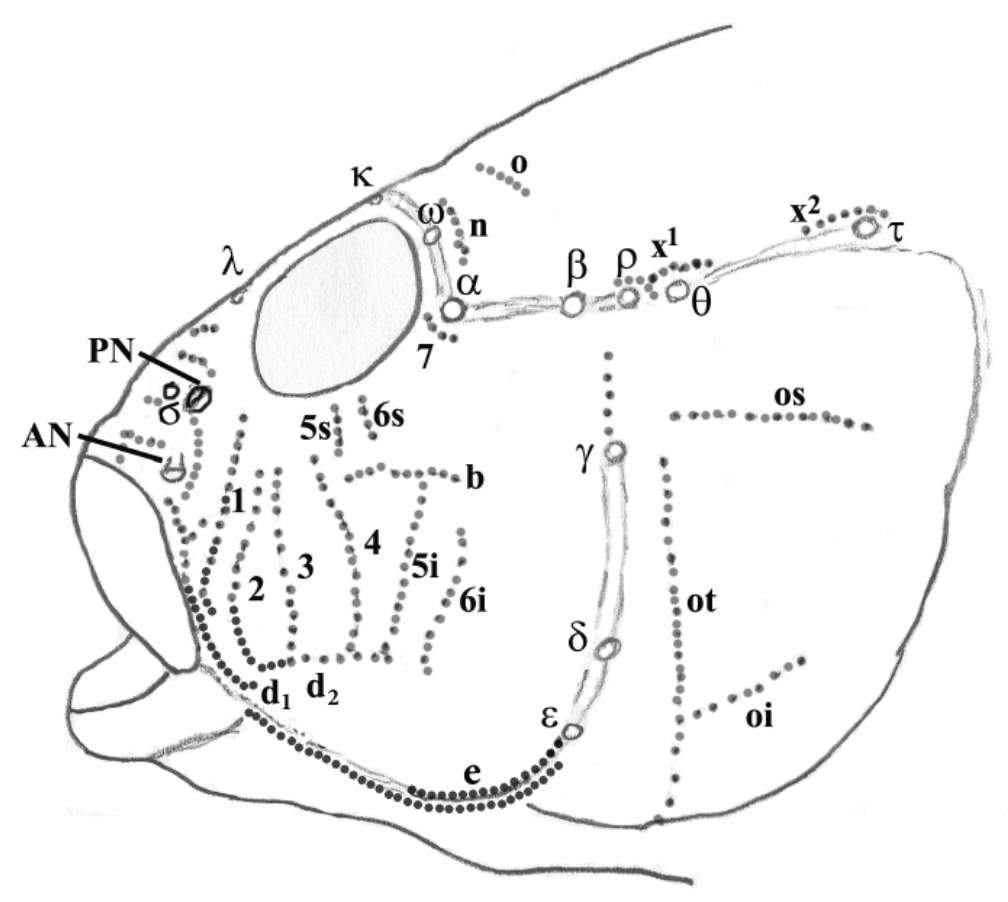

Fig. 3. Diagram of head lateral-line sensory system in the paratype of Ponticola iranicus sp. nov.; pores are designated by Greek letters, rows of neuromasts (genipores/ sensory papillae) by Latin letters and Arabic numerals; AN, anterior nostril, PN, posterior nostril

arms (NF) 46 (Fig. 4); no chromosome polymorphism or sexual dimorphism in chromosome numbers is observed.

Distribution. The new species is found in rivers of the southwestern part of the Caspian Sea: Sefid-Rud and Gisum rivers, as well as rivers of the Anzeli Lagoon drainage (Massuleh, Pasikhan).

Etymology. The name of the species is based on its distribution in Iranian territory of the Caspian Sea basin.

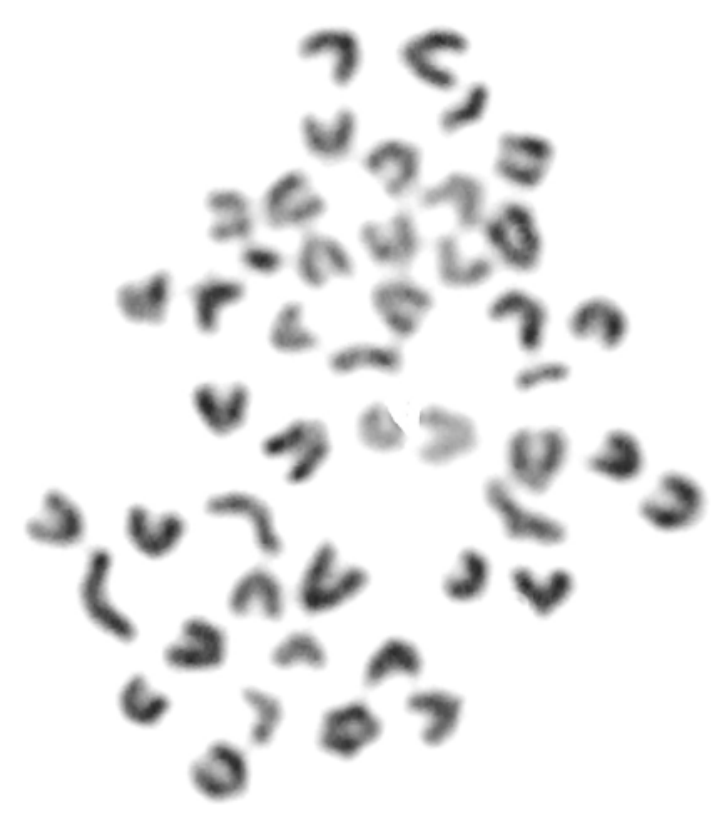

Fig. 4. Metaphase plate of Ponticola iranicus sp. nov.; chromosome number $(2 n)=46$
Ecological features. This goby inhabits freshwater biotopes with a rapid current and the bottom covered by stones and boulders.

Comparative remarks. Ponticola iranicus differs from the freshwater Caspian goby P. cyrius of the Kura River basin in coloration (predorsal area of $P$. cyrius always marbled, first dorsal fin typically with distal dark band or shading and lacking oblique black stripe in anterior part), lower numbers of branched dorsal and anal fin rays (P. cyrius has $D_{2} \mathrm{I} / 15^{1 / 2}-191 / 2$, usually $171 / 2-181 / 2$, and $A$ I/11 $1 / 2-15 \frac{1}{2}$, usually $13^{1 / 2}$ ), significantly shorter anal fin base and longer pelvic disc (Table 2), and in karyotype structure: $P$. cyrius has 36-42 chromosomes with chromosome polymorphism observed for a number of subtelocentric chromosomes (Vasil'eva and Vasil'ev 1994a, 1994b).

Ponticola iranicus is easy distinguishable from P. gorlap, which is widely distributed in the Caspian Sea basin and sympatric with the new species in the Sefid-Rud River, by its colour pattern: P. gorlap is characterized by specific reticulations or mottling on cheeks, upper lips, and pectoral bases, and by lacking a dark spot on anterior part of the first dorsal fin. Moreover, P. gorlap has more branched dorsal fin rays $\left(D_{2} \mathrm{I} / 16^{1 / 2}-181 / 2\right)$, its upper lip usually slightly or not expanded and never swollen, and the karyotype includes 43-46 chromosomes, NF = 46 (Vasil'eva and Vasil'ev 2003, Prazdnikov et al. 2013). Among other Caspian species of the genus Ponticola, $P$. syrman differs noticeably from $P$. iranicus in the presence of ctenoid scales on the nape, at least before dorsal fin, narrow upper lip, of uniform width, never swollen, head depth usually greater than head width, anterior membrane of pelvic disc with very shallow, rounded lateral lobes, and three transverse infraorbital papillae rows below lon- 
gitudinal hyomandibular row $b$ ( $P$. iranicus has only two rows: $5 i$ and 6i). Moreover, according to our unpublished data, $P$. syrman is characterized by wide chromosome polymorphism with $2 \mathrm{n}=32-40, \mathrm{NF}=46$ (populations from the Black Sea and the Sea of Azov basins were investigated). Ponticola ratan ( $P$. ratan goebelii (Kessler, 1874 ) in the Caspian Sea basin), in contrast to $P$. iranicus, has a narrow upper lip, small lateral lobes of pelvic anterior membrane, head laterally depressed, and cheeks not prominent; moreover $P$. ratan is euryhaline species and typically inhabits inshore brackish waters (Miller 2003, Vasil'eva 2007). At the same time, $P$. iranicus belongs to the purely freshwater Ponticola species represented in the Ponto-Caspian basin by another five species according to recent taxonomic concept. In addition to P. cyrius, two freshwater goby species distributed in the Black Sea basin were karyotyped previously. $P$. constructor is characterized by chromosome polymorphism with $2 \mathrm{n}=42-44$ and $\mathrm{NF}=46-48$; this species also differs from $P$. iranicus in greater numbers of branched dorsal fin rays $\left(D_{2} \mathrm{I} / 16^{1 / 2-}\right.$ $19 \frac{1}{2}$, usually $17 \frac{1}{2}$ ) and the first dorsal fin uniformly stippled or with inconspicuous dark banding. Another freshwater species, P. rhodioni Vasil'eva et Vasil'ev, 1994, is more similar to $P$. iranicus having $2 \mathrm{n}=46, \mathrm{NF}=46$, uniform predorsal colour, and the same biotopic preferences: both species occur in habitats with a rapid current and stony bottom, whereas $P$. cyrius and $P$. constructor populate rivers with slow current, sandy and muddy bottom and vegetation (Vasil'eva and Vasil'ev 1994a). However, $P$. rhodioni differs significantly from $P$. iranicus in greater numbers of branched dorsal fin rays $\left(D_{2} I / 16^{1 / 2}-191 / 2\right.$, usually $171 / 2-18 \frac{1}{2}$ ), shorter and rounded pelvic disc (IV $16.0 \%-20.5 \%$ SL with mean values in different populations from $17.4 \%$ to $19.1 \%$ ), and in coloration of the first dorsal fin, usually evenly covered by small speckles or with stripes of small dark speckles on a light background (Vasil'eva and Vasil'ev 1994b, Miller 2003).
Two new freshwater species were described (Kovačić and Engín 2008) from two small streams on the south-eastern coast of the Black Sea (north-eastern Turkey). Both descriptions were based on a few specimens: only five individuals of Ponticola rizensis Kovačić et Engín, 2008 and three individuals of Ponticola turani Kovačić et Engín, 2008 were investigated; at the same time, the majority of their diagnostic characters were morphometric, their study needs representative samples and statistical analysis. That is why their comparison in morphometric data looks doubtful; however, P. rizensis differs from $P$. iranicus in colour of the first dorsal fin (it has "one lower longitudinal band, and two upper longitudinal rows of brown dots"), the presence of seven rays in this fin, and according to Kovačić and Engín (2008) in shorter pelvic disc, greater interorbital width and discontinuous sub-orbital longitudinal row $d$ of lateral line system consisting of three parts: $d_{1}, d_{2}$, and $d_{3}$. A similarly divided sub-orbital row $d$ is described for the second species P. turani (see Kovačić and Engín 2008,). As opposed to these species, the posterior longitudinal row $d_{2}$ in $P$. iranicus is continuous (Fig. 3). In addition, $P$. turani is characterized by atypical structure of lateral line pore $\lambda$ which looks "as transversal furrow with two openings on the ends" (Kovačić and Engín 2008). Moreover this species has only two longitudinal rows of brown dots on the first dorsal fin, greater numbers of branched dorsal fin rays $\left(D_{2} \mathrm{I} / 18^{1 / 2}-191 / 2\right)$, and shorter interorbit distance (0.3-0.5 eye diameter) (Kovačić and Engín 2008).

Evolution remarks. At present, the number of described freshwater goby species in the Ponto-Caspian basin increased to six. These species demonstrate mosaic pattern of both morphological (including colour pattern) and karyological features. This may constitute an evidence for their polyphyletic origins, similarly to freshwater forms in other anadromous or euryhaline fish species. However, in contrast to the majority of situations observed in salmons, lam-

Table 2

Morphometric characters differentiating Ponticola iranicus sp. nov. and P. cyrius in studied samples of both species

\begin{tabular}{|c|c|c|c|c|c|}
\hline \multirow{2}{*}{ Species } & \multirow{2}{*}{ Locality } & & \multicolumn{3}{|c|}{ Character } \\
\hline & & & $\mathrm{SL}[\mathrm{mm}]$ & $1 \mathrm{~A}$ & IV \\
\hline \multirow{4}{*}{ 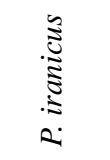 } & \multirow{2}{*}{$\begin{array}{l}\text { Gisum River } \\
\quad(n=7)\end{array}$} & Range & $44.0-60.7$ & $22.6-25.4$ & $19.0-24.7$ \\
\hline & & Mean & 63.7 & 24.2 & 22.3 \\
\hline & \multirow{2}{*}{$\begin{array}{l}\text { Anzali Lagoon } \\
\quad(n=38)\end{array}$} & Range & $40.8-101.3$ & $22.5-29.9$ & $18.6-22.9$ \\
\hline & & Mean \pm SD & $66.1 \pm 0.95$ & $25.0 \pm 1.64$ & $20.8 \pm 0.97$ \\
\hline \multirow{8}{*}{ 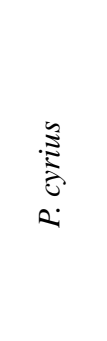 } & \multirow{2}{*}{$\begin{array}{l}\text { Kura River at Borzhom } \\
\qquad(n=13)\end{array}$} & Range & $39.3-85.5$ & $26.8-29.8$ & $16.4-20.6$ \\
\hline & & Mean $( \pm \mathrm{SD})$ & 57.9 & $27.9 \pm 0.94$ & $18.8 \pm 1.12$ \\
\hline & \multirow{2}{*}{$\begin{array}{l}\text { Kura River at Akhaldabo } \\
\qquad(n=30)\end{array}$} & Range & $45.2-94.0$ & $24.5-30.0$ & $14.8-19.9$ \\
\hline & & Mean $( \pm \mathrm{SD})$ & 63.1 & $27.7 \pm 1.42$ & $17.7 \pm 1.37$ \\
\hline & \multirow{2}{*}{$\begin{array}{l}\text { Tbilisi Reservoir } \\
\quad(n=15)\end{array}$} & Range & $39.3-56.3$ & $25.6-30.1$ & $17.1-19.5$ \\
\hline & & Mean $( \pm \mathrm{SD})$ & 50.8 & $27.1 \pm 1.12$ & $18.0 \pm 0.62$ \\
\hline & \multirow{2}{*}{$\begin{array}{l}\text { Khrami River } \\
\quad(n=10)\end{array}$} & Range & $54.1-71.7$ & $24.6-30.4$ & $16.5-18.6$ \\
\hline & & Mean $( \pm \mathrm{SD})$ & 62.0 & $28.3 \pm 1.64$ & $17.5 \pm 0.76$ \\
\hline
\end{tabular}

$\mathrm{SL}=$ standard body length, $1 \mathrm{~A}=$ length of anal fin base, $\mathrm{lV}=$ length of ventral disc, $n=$ number of fish studied, $\mathrm{SD}=$ standard deviation; Source: the presently reported study (for P. iranicus from Gisum), Ahnelt and Holčík 1996 (for P. iranicus from Anzali Lagoon), and Vasil'eva and Vasil'ev 1994b (for P. cyrius; four samples from the Kura River drainage). 
preys, etc. freshwater gobies reached significant morphological divergence from their euryhaline ancestors resulting in their distinguishing as obvious separate "morphological species". Further phylogenetic studies by molecular genetic methods are required for evidences of the origin of particular freshwater species and clarifying of common trends in the evolution of the Ponto-Caspian group.

Below we present a new key to the Caspian species of the genus Ponticola that includes enlarged scope of characteristics for easier identification.

A key to the Caspian species of the genus Ponticola

1a - Pelvic anterior membrane with rounded shallow lateral lobes not more than one-sixth width of anterior membrane; nape with ctenoid scales in middle and posterior parts; upper lip of uniform width, not swollen; head usually higher than a width; typically inhabiting inshore brackish waters of estuaries ....P. syrman

$1 \mathrm{~b}$ - Pelvic anterior membrane with angular lateral lobes, in length about one-sixth to almost half width of anterior edge; nape scales cycloid or rarely ctenoid predorsally (if ctenoid scales present - in P. gorlap - pelvic anterior membrane lateral lobes large, at least one-fifth width of rear edge); upper lip at least slightly swollen posteriorly; head wider than deep (if head higher than a width - in P. ratan - nape scales cycloid only); euryhaline and freshwater

...2

2a - Pelvic anterior membrane lateral lobes small, not more than one-fifth width of rear edge; head laterally depressed, its depth slightly less to somewhat greater than width; cheeks not prominent; upper lip narrow, its width from 0.4 to two-thirds lateral preorbital width; euryhaline, typically inhabits pleiomesohaline waters (8\%-15\%o

$P$. ratan goebelii

$2 \mathrm{~b}-$ Pelvic anterior membrane lateral lobes large, at least one-fifth width of rear edge; head oblate, always wider than deep; cheeks prominent; upper lip width at least three-fifths lateral preorbital width; euryhaline inshore and freshwater .

$3 \mathrm{a}-$ Cheeks, upper lips, and pectoral bases with reticulations or mottling; first dorsal fin with 3-4 lines of small dark spots, lacking clear dark band; upper lip not swollen; in some populations specimens with ctenoid nape scales occur; euryhaline, inhabits inshore brackish waters and lower parts of rivers. P. gorlap

$3 b$ - Cheeks, upper lips, and pectoral bases without reticulations or mottling; first dorsal fin with clear dark band; upper lip more or less swollen; nape scales cycloid only; freshwater, inhabits upper and middle reaches of the river.

4a - Predorsal area always marbled; first dorsal fin with distal dark band or shading; $D_{2}$ typically with $17 \frac{1}{2}-18 \frac{1}{2}$ branched rays; anal fin typically with $13 \frac{1}{2}$ branched rays.. P. cyrius

$4 \mathrm{~b}$ - Predorsal area uniform, dark grey; first dorsal fin with oblique black stripe between the first two or three rays; $D_{2}$ typically with $15 \frac{1}{2}-16^{1 / 2}$ branched rays; anal fin typically with $11 \frac{1 / 2}{2}-12 \frac{1}{2}$ branched rays

\section{ACKNOWLEDGEMENTS}

The authors are very grateful to S. Eagdery, K. Abbasi, M. Mansuri, M. Mohammadi, K. Ghasemzadeh, and H. Parnoush for their help in collecting the material. This taxonomic study and field works were partially supported by the Russian Foundation for Basic Researches, Project No. 13-04-00279-a, and the University of Guilan, Project No. 93-1754, and the analysis of museum collections - by the Russian Scientific Fund, Project No. 14-50-00029.

\section{REFERENCES}

Ahnelt H., Holčík J. 1996. Distribution of two species of the genus Neogobius (Pisces: Gobiidae) in the catchment area of the southern Caspian Sea. Acta Universitatis Carolinae Biologica 40 (1/2): 99-114.

Berg L.S. 1949. Ryby presnyh vod SSSR i sopredel'nyh stran. [Fishes of fresh waters of the USSR and adjacent countries.] Part 3. Izdatel'stvo Akademii Nauk SSSR, Moskva-Leningrad. [In Russian.]

Bogutskaâ N.G. [Bogutskaya N.G.], Kiâško P.V. [Kijashko P.V.], Naseka A.M., Orlova M.I. 2013. Opredelitel' ryb i bespozvonočnyh Kaspijskogo morâ. T. 1. Ryby i mollûski [Identification keys for fish and invertebrates of the Caspian Sea. V. 1. Fishes and mollusks.] Tovariŝestvo naučnyh izdanij KMK, Sankt-Peterburg-Moskva. [In Russian with English summary.]

Coad B.W. 2015. Freshwater fishes of Iran. [Access on 5 January 2015] www.briancoad.com

Deržavin A.N. [Derjavin A.N.] 1926. Ryby reki Karasu. [Fishes of the Karasu River.] Izvestiâ Bakinskoj ihtiologičeskoj laboratorii 2 (1): 161-184. [In Russian.]

Deržavin A.N. [Derjavin A.N.] 1934. Presnovodnye ryby ûžnogo poberež'â Kaspiâ. [Freshwater fishes of the southern coast of the Caspian Sea.] Trudy Azerbajdžanskogo otdeleniâ Zakavkazskogo filiala Akademii Nauk SSSR, Sektor zoologii 7: 91-126. [In Russian with English summary.]

Esmaeili H.R., Coad B.W., Gholamifard A., Nazari N., Teimory A. 2010. Annotated checklist of the freshwater fishes of Iran. Zoosystematica Rossica 19 (2): 361-386.

Il'in B.S. [Iljin B.S.] 1927. Opredelitel' byčkov (Fam. Gobiidae) Azovskogo i Čërnogo morej. (Predvaritel'noe soobŝenie). [Key for gobies (Fam. Gobiidae) from the Sea of Azov and Black Sea. (Preliminary announcement).] Trudy Azovsko-Černomorskoj naučno-promyslovoj èkspedicii No. 2: 128-143. [In Russian.]

Kovačić M., Engín S. 2008. Two new species of Neogobius (Gobiidae) from northeastern Turkey. Cybium 32 (1): 73-80.

Levan A., Fredga A., Sandberg A.A. 1964. Nomenclature for centromeric position on chromosomes. Hereditas 52 (2): 201-220.

DOI: 10.1111/j.1601-5223.1964.tb01953.x

Medvedev D.A., Sorokin P.A., Vasil'ev V.P., Chernova N.V., Vasil'eva E.D. 2013. Reconstruction of phylogenetic relations of Ponto-Caspian gobies (Gobiidae, 
Perciformes) based on mitochondrial genome variation and some problems of their taxonomy. Journal of Ichthyology 53 (9): 702-712. DOI: $10.1134 / \mathrm{S} 0032945213060064$

Miller P.J. 1986. Gobiidae. Pp. 1019-1085. In: Whitehead P.J.P., Bauchot M.-L., Hureau J.-C., Nielsen J., Tortonese E. (eds.) Fishes of the North-eastern Atlantic and Mediterranean. Vol. 3. UNESCO, Paris.

Miller P.J. (ed.) 2003. The freshwater fishes of Europe. V. 8/I. Mugilidae, Atherinidae, Atherinopsidae, Blenniidae, Odontobutidae, Gobiidae 1. AULA-Verlag, Wiebelsheim, Germany.

Miller P.J. (ed.) 2004. The freshwater fishes of Europe. V. 8/II. Gobiidae 2. AULA-Verlag, Wiebelsheim, Germany.

Miller P.J., Vasil'eva E.D. 2003. Neogobius Iljin, 1927. Pp. 163-171. In: Miller P.J. (ed.) The freshwater fishes of Europe. V. 8/I. Mugilidae, Atherinidae, Atherinopsidae, Blenniidae, Odontobutidae, Gobiidae 1. AULA-Verlag, Wiebelsheim, Germany.

Neilson M.E., Stepien C.A. 2009. Escape from the Ponto-Caspian: Evolution and biogeography of an endemic goby species flock (Benthophilinae: Gobiidae: Teleostei). Molecular Phylogenetics and Evolution 52 (1): 84-102.

DOI: 10.1016/j.ympev.2008.12.023

Prazdnikov D.V., Vasil'ev V.P., Vasil'eva E.D. 2013. Polymorphism and interpopulation variability of the karyotype in the Caspian bighead goby Neogobius gorlap (Gobiidae, Perciformes). Journal of Ichthyology 53 (6): 459-464.

DOI: $10.1134 / \mathrm{S} 0032945213040073$

Vasil'ev V.P. 1978. Hromosomnyj polimorfizm u smaridy - Spicara smaris (Pisces, Centracanthidae). [Chromosome polymorphism in pickerel - Spicara smaris (Pisces, Centracanthidae).] Zoologičeskij žurnal 57 (8): 1276-1278. [In Russian.]

Vasil'eva E.D. 2007. Ryby Čërnogo morâ. Opredelitel' morskih, solonovatovodnyh, èvrigalinnyh i prohodnyh vidov s cvetnymi illûstraciâmi, sobrannymi S.V. Bogorodskim. [Fishes of the Black Sea. Key to marine, brackish-water, euryhaline, and anadromous species with colour illustrations collected by S.V. Bogorodsky.] Izdatel'stvo VNIRO, Moskva. [In Russian with English summary.]

Vasil'eva E.D., Vasil'ev V.P., Pinčuk V.I. [Pinchuk V.I.] 1993. Kraniologičeskij analiz byčkov podroda Ponticola Iljin, 1927. III. Sravnitel'no-morfologičeskoe issledovanie Neogobius kessleri, N. ratan i dopolnitel'nye svedeniâ po $N$. syrman v svâzi s diagnostikoj i ob"ëmom podroda Ponticola. [Craniological analysis on gobies from the subgenus Ponticola Iljin, 1927. III. Comparative morphological investigation of Neogobius kessleri, $N$. ratan and additional data on $N$. syrman in relation with diagnostic and structure of the subgenus Ponticola.] Voprosy ihtiologii 33 (5): 609-617. [In Russian.]

Vasil'eva E.D., Vasil'ev V.P. 1994a. K sistematike kavkazskih rečnyh byčkov (Gobiidae): dannye kraniologičeskogo i kariologičeskogo analizov i raspredeleniâ po biotopam râda populâcij černomorskogo i kaspijskogo bassejnov. [For the taxonomy of the Caucasian riverine gobies (Gobiidae): results of craniological and karyological analyses and distribution in different biotopes of several populations from the Black Sea and Caspian basins.] Voprosy ihtiologii 34 (2): 187-194. [In Russian.]

Vasil'eva E.D., Vasil'ev V.P. 1994b. Sistematika kavkazskih rečnyh byčkov (Gobiidae) v svete sovremennyh dannyh s opisaniem novogo vida Neogobius rhodioni sp. nova. [Systematics of the Caucasian riverine gobies (Gobiidae) in light of recent data with description of a new species Neogobius rhodioni sp. nova.] Voprosy ihtiologii 34 (6): 747-758. [In Russian.]

Vasil'eva E., Vasil'ev V.P. 2003. Neogobius gorlap Iljin in Berg, 1949. Pp. 253-264. In: Miller P.J. (ed.) The freshwater fishes of Europe. V. 8/I. Mugilidae, Atherinidae, Atherinopsidae, Blenniidae, Odontobutidae, Gobiidae 1. AULA-Verlag, Wiebelsheim, Germany.

Received: 2 February 2015

Accepted: 28 March 2015

Published electronically: 30 June 2015 